\title{
Distribution and Solubilization of Particulate Gluconate Dehydrogenase and Particulate 2-Ketogluconate Dehydrogenase in Acetic Acid Bacteria
}

\author{
Emiko Shinagawa, Toshikazu Chiyonobu, Osao Adachi \\ and Minoru Ameyama \\ Department of Agricultural Chemistry, Yamaguchi University, \\ Yamaguchi, Japan \\ Received August 25, 1975
}

\begin{abstract}
The distribution of two particulate enzymes, gluconate dehydrogenase (GDH) and 2-ketogluconate dehydrogenase ( $2 \mathrm{KGDH})$, was investigated with cell free extract through 26 strains of genus Acetobacter and genus Gluconobacter. GDH activity was found in the cell free extracts from all strains of genus Gluconobacter and two species of genus Acetobacter, $A$. acet $i$ and $A$. aurantium. High activity of $2 \mathrm{KGDH}$ was also found in the pigment-producing strains of genus Gluconobacter.

Best solubilization of particulate enzymes was attained with the highest recovery when $10 \mathrm{mg}$ of Triton X-100 and $30 \mathrm{mg}$ of protein of particulate fractions in $1 \mathrm{ml}$ of $0.01 \mathrm{M}$ phosphate buffer, $\mathrm{pH} 6.0$, are incubated for $9 \mathrm{hr}$ at $5^{\circ} \mathrm{C}$ with continuous stirring.

By comparison of the total enzyme activity of particulate enzymes with that of NAD(P)linked enzymes in the cell free extract, it was obvious that the formation of ketogluconates by particulate enzymes was much more predominant, roughly over 100 times higher, as that of NAD(P)-linked enzymes.
\end{abstract}

It has been well known that the growing cells or resting cells of acetic acid bacteria belonging to Suboxydans or Mesoxydans group have a marked biological activity to oxidize gluconate (GA) to 2-ketogluconate (2KGA) and 5-ketogluconate (5KGA). De Ley and Stouthamer ${ }^{1)}$ have suggested that GA was oxidized by three different enzymes, two of which are NAD (P)-linked dehydrogenases yielding $2 \mathrm{KGA}$ or 5KGA, and particulate oxidase yielding $2 \mathrm{KGA}$, in the nonphosphorylative ketogenic metabolism of the acetic acid bacteria. Our investigations have been focused on systematic understandings of these nonphosphorylative metabolic pathways of carbohydrates in the acetic acid bacteria and other oxidative bacteria. We have reported on the purification and characterization of NAD(P)-linked 2ketogluconate reductase $\mathrm{e}^{2 \sim 4)}$ and 5-ketogluconate reductase ${ }^{3)}$ from Gluconobacter liquefaciens. More recently, we have crystallized the 2-ketogluconate reductase for the first time from $G$. liquefaciens ${ }^{6,7)}$ and Acetobacter rancens. $^{7,81}$

We have also found the occurrence of two coenzyme independent dehydrogenases, gluconate dehydrogenase (GDH) yielding $2 \mathrm{KGA}$ and 2-ketogluconate dehydrogenase (2KGDH) yielding 2,5-diketogluconate, in the particulate fractions of $G$. liquefaciens. These particulate dehydrogenases have been little investigated, although Katznelson et $a l^{9,10)}$ reported that the latter enzyme from $G$. melanogenus dehydrogenated 2KGA to 2,5-diketogluconate in the absence of NAD(P). Moreover, it was also reported that $2 \mathrm{KGDH}$ (EC 1. 1. 99. 4) was partially purified about 40 -fold from the particulate fraction of the same strain. ${ }^{10}$ However, characterization and physiological roles of these particulate enzymes in the cells of acetic acid bacteria have been little investigated up to today. We believe that it has an immediate importance to characterize in more details these metabolic pathways of the oxidative bacteria.

In this paper, therefore, the authors wish to 
deal with the distribution and solubilization of particulate enzymes of GDH and $2 \mathrm{KGDH}$ in the species belonging to the genus Acetobacter and genus Gluconobacter.

\section{MATERIALS AND METHODS}

Chemicals. All the chemicals used in this work were commercial products. Yeast extract and pyridine coenzymes were kindly supplied from the Oriental Yeast Co., Ltd. Sodium gluconate for culture medium was a kind gift from the Nagase Co., Ltd. and the Fujisawa Pharmaceutical Ind. Co., Ltd. DEAE-Cellulose was generously supplied from the Midorijyuji Co., Ltd. Hydroxylapatite was prepared according to the method of Tiselius et al. ${ }^{11}$

Microorganisms. The microbial strains used in this work were supplied from the Institute for Fermentation, Osaka (IFO). All the strains used are listed in Table I.

Medium and cultivation. The medium for culture consisted of $20 \mathrm{~g}$ of Na-gluconate, $5 \mathrm{~g}$ of glucose, $3 \mathrm{~g}$ of glycerol, $5 \mathrm{~g}$ of polypeptone, $2 \mathrm{~g}$ of yeast extract, and $200 \mathrm{ml}$ of potato extract ${ }^{12}$ in 1 liter of tap water. The pH of the medium was spontaneously settled on pH 6.5 when all of these constituents were present.

Various strains of the acetic acid bacteria were transferred from the potato-glycerol agar slant ${ }^{12}$ ) to $100 \mathrm{ml}$ of the medium in $500 \mathrm{ml}$ shaking flasks and the cultivation was carried out at $30^{\circ} \mathrm{C}$ for $24 \mathrm{hr}$ with reciprocal shaking.

Preparation of cell free extract. The cells in the cultured broth were harvested by continuous flow centrifugation and washed with $0.01 \mathrm{~m}$ potassium phosphate buffer, $\mathrm{pH}$ 6.0. The washed cells were suspended in appropriate volumes of the buffer containing $1 \mathrm{~mm}$ 2 -mercaptoethanol. The cell suspension was treated with $20 \mathrm{kHz}$ Tomi-Seiko ultrasonic oscillator for $20 \mathrm{~min}$ with an exception of $G$. dioxyacetonicus which was disrupted in a Vibrogen Cell Mill from the Edmund Buhler for 15 min using $0.3 \mathrm{~mm}$ glass beads. The cell debris was removed by centrifugation at $12,000 \times g$ for $20 \mathrm{~min}$.

Fractionation of cell free extract. Cell free extract was centrifuged at $184,000 \times g$ for 60 min by a Hitachi model $55 \mathrm{P}$ ultracentrifuge. Precipitate was dispersed in a small amount of the buffer and centrifuged again as above. The clear supernatant solutions were combined together and designated as a "soluble fraction" and the resultant precipitate was subjected to Triton $X-100$ treatment to solubilize the enzyme. Triton $\mathrm{X}-100$ was added to a final concentration of 1 per cent to the suspension of the precipitate. The mixture was stirred gently for $9 \mathrm{hr}$ at $5^{\circ} \mathrm{C}$ and then centrifuged at $184,000 \times g$ for $60 \mathrm{~min}$. The supernatant solution was designated as a "particulate fraction."

Solubilization. Studies for the best conditions of solubilization of particulate enzymes were carried out at $0 \sim 5^{\circ} \mathrm{C}$, unless otherwise stated. As both particulate enzyme activities of GDH and $2 \mathrm{KGDH}$ were never found in the soluble fractions, the following simplifed procedures were mainly used for convenience. The cell free extract was fractionated with ammonium sulfate and the fraction from 0 to 30 per cent saturation of the salt was collected and pooled in a cold room. The precipitate at this stage usually contained all of the particulate enzyme activities. The ammonium sulfate fraction was dissolved in $0.01 \mathrm{M}$ buffer, $\mathrm{pH} 6.0$, and dialyzed against the same buffer for $16 \mathrm{hr}$. The dialyzed solution was centrifuged at $12,000 \times g$ for $20 \mathrm{~min}$ and the supernatant solution (equivalent to $30 \mathrm{mg}$ protein $/ \mathrm{ml}$ ) was incubated with surface active agents under various conditions. After incubation, the mixture was centrifuged at $184,000 \times g$ for $60 \mathrm{~min}$ to remove insoluble materials and the supernatant solution was used as enzyme solution.

Purification of particulate enzymes. GDH and 2$\mathrm{KGDH}$ from the cell free extract of $G$. liquefaciens were highly purified about 160 - to 240 -fold by a procedure involving ammonium sulfate fractionation, solubilization by Triton $X-100$, and DEAE-cellulose-, and hydroxylapatite-column chromatographies. The solubilized enzyme was chromatographed on a DEAEcellulose column which had been equilibrated with $0.01 \mathrm{M}$ phosphate buffer, $\mathrm{pH} 6.0$, containing 0.1 per cent Triton X-100. Active fraction of GDH was passed through the DEAE-cellulose column under these chromatographic conditions, and $2 \mathrm{KGDH}$ was eluted from the column with $0.2 \mathrm{M}$ phosphate buffer, $\mathrm{pH} 6.0$. $\mathrm{GDH}$ and $2 \mathrm{KGDH}$ solutions were applied to a hydroxylapatite column separately which had been equilibrated with $0.01 \mathrm{M}$ phosphate buffer, $\mathrm{pH} 6.0$. The columns were washed with excess amounts of $0.01 \mathrm{M}$ phosphate buffer, $\mathrm{pH} 6.0$, to remove Triton $\mathrm{X}-100$. The enzyme eluted under a linear gradient elution made by $0.01 \mathrm{M}$ and $0.4 \mathrm{M}$ of the buffer. The active fractions of GDH or $2 \mathrm{KGDH}$ were eluted at about $0.2 \mathrm{M}$ of the buffer. Specific activity of GDH and $2 \mathrm{KGDH}$ thus obtained was 3770 and 5660 , respectively.

Enzyme assays. GDH and $2 \mathrm{KGDH}$ activities of particulate fractions were determined spectrophotometrically by measuring the decrease of absorbancy of 2,6-dichlorophenolindophenol at $600 \mathrm{~nm}$. The reaction mixture contained $1 \mu$ mole of 2,6-dichlorophenolindophenol, $0.33 \mu$ mole of phenazine methosulfate, $100 \mu$ moles of substrate (GA or $2 \mathrm{KGA}$ ), $200 \mu$ moles 
of potassium phosphate buffer, $\mathrm{pH} 6.0$, and the enzyme solution in a total volume of $3.0 \mathrm{ml}$. The enzyme reaction was carried out in a Hitachi model 124 spectrophotometer attached with a recorder at $25^{\circ} \mathrm{C}$. The molecular extinction coefficient of 2,6-dichlorophenolindophenol of $14,000 \mathrm{M}^{-1}$ was cited for the calculation of enzyme unit. ${ }^{192}$ One unit of the enzyme activity was defined as the amount of enzyme catalyzing a change of $1 \mu$ mole of 2,6-dichlorophenolindophenol per minute under the standard assay conditions. NAD(P)linked enzymes were assayed as mentioned before, $\left.{ }^{8,18}\right)$ and one unit of this assay was defined as the amount of enzyme catalyzing a change of $1 \mu$ mole of $\mathrm{NAD}(\mathrm{P}) \mathrm{H}$ per minute.

Protein determination. Protein content was determined by the methods by Lowry et al. ${ }^{14)}$ using bovine serum albumin as the standard.

Electrophoresis. Disc gel electrophoresis was performed under essentially the same conditions described by Davis ${ }^{15)}$ using a 7.5 per cent polyacrylamide gel and Tris-glycine buffer, $\mathrm{pH} 8.3$.

Location of particulate enzyme was detected by staining the gel in the standard medium containing $0.1 \mathrm{M}$ substrate, $0.4 \mathrm{mg} / \mathrm{ml}$ nitro blue tetrazolium, $0.14 \mathrm{mg} / \mathrm{ml}$ phenazine methosulfate and $0.03 \mathrm{M}$ potassium phosphate buffer, $\mathrm{pH} 6.0$. After staining for 5 to $10 \mathrm{~min}$ at $25^{\circ} \mathrm{C}$ in the dark, colorization was stopped by transferring the gel into 7.0 per cent acetic acid. The staining intensity and location of each band were determined by tracing densitometric scanning in Toyo Densitorol DMU-33C.

Paper chromatography of reaction products. Paper chromatography was performed by the method described in the previous paper ${ }^{2}$ except that the incubation system contained $0.33 \mu$ mole of phenazine methosulfate, $100 \mu$ moles of substrate, $100 \mu$ moles of potassium phosphate buffer, $\mathrm{pH} 6.0$, and enzyme solution in a total volume of $2.0 \mathrm{ml}$.

Table I. Distribution of Particulate Dehydrogenases in the Cell Free Extract and Particulate Fraction from Acetic Acid Bacteria The data are expressed as a specific activity.

\begin{tabular}{|c|c|c|c|c|}
\hline \multirow{2}{*}{ Strain } & \multicolumn{2}{|c|}{ Cell free extract } & \multicolumn{2}{|c|}{ Particulate fraction } \\
\hline & GDH & $2 \mathrm{KGDH}$ & GDH & $2 \mathrm{KGDH}$ \\
\hline Acetobacter & 1 & 0 & 16 & 0 \\
\hline A. aceti IFO 3284 & 1 & 0 & 16 & 0 \\
\hline A. ascendens IFO 3299 & 0 & 0 & 0 & 0 \\
\hline A. acetosus IFO 3129 & 0 & 1 & 0 & 7 \\
\hline A. xylinum IFO 3288 & 0 & 0 & 0 & 0 \\
\hline A. kützingianus IFO 3222 & 0 & 0 & 0 & 0 \\
\hline A. rancens IFO 3298 & 0 & 0 & 0 & 0 \\
\hline A. acetigenus IFO 3277 & 0 & 0 & 0 & 0 \\
\hline A. aurantium IFO $3245^{a \text { ? }}$ & 9 & 2 & 57 & 18 \\
\hline A. aurantium IFO $3247^{a)}$ & 2 & 0 & 31 & 0 \\
\hline $\begin{array}{l}\text { Gluconobacter } \\
\quad \text { G. liquefaciens IFO } 12388^{a} \text { ) }\end{array}$ & 22 & 15 & 89 & 22 \\
\hline G. melanogenus IFO $\left.12257^{a}\right\rangle$ & 37 & 31 & 429 & 86 \\
\hline G. melanogenus IFO $3293^{a}$ & 6 & 10 & 36 & 15 \\
\hline G. sphaericus IFO $12467^{a\rangle, 18\}}$ & 55 & 56 & 189 & 10 \\
\hline G. oxydans IFO 3189 & 9 & 0 & 491 & 0 \\
\hline G. axydans IFO 3287 & 2 & 0 & 21 & 0 \\
\hline G. dioxyacetonicus IFO 3272 & 27 & 1 & 386 & 15 \\
\hline G. cerinus IFO 3262 & 6 & 0 & 32 & 0 \\
\hline G. cerinus IFO 3265 & 9 & 0 & 171 & 0 \\
\hline G. cerinus IFO 3267 & 1 & 0 & 20 & 0 \\
\hline G. gluconicus IFO 3171 & 7 & 0 & 81 & 0 \\
\hline G. roseus IFO 3990 & 4 & 0 & 34 & 0 \\
\hline G. albidus IFO 3250 & 11 & 0 & 166 & 0 \\
\hline G. suboxydans IFO 3172 & 7 & 1 & 18 & 3 \\
\hline G. suboxydans IFO 12528 & 5 & 0 & 11 & 0 \\
\hline G. suboxydans var. $\alpha$ IFO 3254 & 2 & 0 & 11 & 0 \\
\hline
\end{tabular}

a) The pigment-producing strains. 


\section{RESULTS AND DISCUSSION}

Distribution of particulate $G D H$ and $2 \mathrm{KGDH}$

The distribution of particulate GDH and 2KGDH was surveyed with cell free extract of the genus Acetobacter and genus Gluconobacter. As shown in Table I, GDH activities were found in the cell free extract from all strains of genus Gluconobacter and two species of genus Acetobacter, in which $A$. aceti is in Mesoxydans group and $A$. aurantium is classified as an intermediate type strain of acetic acid bacteria. $^{16,17)}$ High activities of particulate $2 \mathrm{KGDH}$ were also found in the pigment-producing strains of Gluconobacter listed in Table I.

The results thus obtained with cell free extract were further ascertained with soluble and particulate fractions in more details. Both particulate enzyme activities of GDH and $2 \mathrm{KGDH}$ did not occur in soluble fractions of the genus Acetobacter and genus Gluconobacter even in the presence of all constituents for particulate enzyme activity. As expected, all the enzyme activities of $\mathrm{GDH}$ and $2 \mathrm{KGDH}$ predominantly occurred in the particulate fractions. The distribution of GDH and $2 \mathrm{KGDH}$ of the particulate fractions showed the same results as obtained with cell free extract. These results also suggest the possibility to solubilize the enzymes by a surface active agent, and the solubilization could be actually performed by Triton X-100.

\section{Identification of reaction products produced by cell free extract}

As shown in Table II, the reaction products by the particulate enzymes were examined with cell free extracts and GA or $2 \mathrm{KGA}$ as substrate. Although no reaction products of $\mathrm{GA}$ or 2KGA could be detected by the enzymes from genus Acetobacter, the cell free extracts from some of the species of genus Gluconobacter, except $G$. dioxyacetonicus and two strains of G. suboxydans produced $2 \mathrm{KGA}$, but not $5 \mathrm{KGA}$ from GA. However, the cell free extracts from $G$. dioxyacetonicus and two strains of $G$. suboxydans produced 5KGA from $\mathrm{GA}$ as they are designated as 5KGA-producing

Table II. Reaction Products from Gluconate or 2-Ketogluconate by Cell Free Extract

\begin{tabular}{|c|c|c|c|c|}
\hline \multirow{2}{*}{\multicolumn{2}{|c|}{ Strain }} & \multicolumn{3}{|c|}{ Product } \\
\hline & & $\begin{array}{c}\text { 2-Keto- } \\
\text { gluconate }^{a}\end{array}$ & $\begin{array}{c}\text { 5-Keto- } \\
\text { gluconate }^{a)}\end{array}$ & $\begin{array}{l}\text { 2,5-Diketo- } \\
\text { gluconate }^{b)}\end{array}$ \\
\hline & G. liquefaciens IFO $\left.12388^{\circ}\right)$ & + & & + \\
\hline & G. melanogenus IFO $12257^{c)}$ & + & & + \\
\hline & G. melanogenus IFO $3293^{c}$ & + & & + \\
\hline & G. sphaericus IFO $12467^{c), 19)}$ & + & & + \\
\hline & G. oxydans IFO 3189 & + & & \\
\hline & G. oxydans IFO 3287 & & + & \\
\hline & G. dioxyacetonicus IFO 3272 & + & & \\
\hline & G. cerinus IFO 3262 & + & & \\
\hline & G. cerinus IFO 3265 & + & & \\
\hline & G. cerinus IFO 3267 & + & & \\
\hline & G. gluconicus IFO 3171 & + & & \\
\hline & G. roseus IFO 3990 & + & & \\
\hline & G. albidus IFO 3250 & + & & \\
\hline & G. suboxydans IFO 3172 & + & & \\
\hline & G. suboxydans IFO 12528 & & + & \\
\hline & G. suboxydans var. $\alpha$ IFO 3254 & & + & \\
\hline a) & Reaction product from gluconat & ate. & & \\
\hline o) & Reaction product from 2 -ketoglu & substrate. & & \\
\hline
\end{tabular}


Gluconobacter. This interesting finding suggests that two kinds of GDH, yielding $2 \mathrm{KGA}$ or $5 \mathrm{KGA}$, must be present in the genus Gluconobacter. In addition, the cell free extract from the pigment-producing strains of Gluconobacter catalyzed the formation of 2,5diketogluconate from $2 \mathrm{KGA}$. These results are in fairly good agreement with the distribution of particulate enzymes shown in Table I.

Effect of various surface active agents on the solubilization of particulate enzymes

Various surface active agents were added to the particulate fractions to check the effect of solubilization of the enzymes. Incubation of particulate fractions with surface active agents was performed at $5^{\circ} \mathrm{C}$ for $9 \mathrm{hr}$ under continuous shaking. As shown in Table III, sodium deoxycholate and Triton $\mathrm{X}-100$ were found to be the best of all surface active agents tested to solubilize the particulate $2 \mathrm{KGDH}$ with a good

Table III. Effect of Surface Active Agents on Solubilization of Particulate Enzymes

\begin{tabular}{|c|c|c|c|}
\hline \multirow{2}{*}{ Reagent } & \multirow{2}{*}{$\begin{array}{l}\text { Conc. } \\
(\%)\end{array}$} & \multicolumn{2}{|c|}{ Recovery $(\%)$} \\
\hline & & $2 \mathrm{KGDH}$ & GDH \\
\hline \multirow[t]{2}{*}{ Sodium deoxycholate } & 0.5 & 86 & 92 \\
\hline & 1.0 & 4 & 26 \\
\hline \multirow[t]{2}{*}{ Sodium stearate } & 0.5 & 0 & 2 \\
\hline & 1.0 & 1 & 0 \\
\hline \multirow[t]{2}{*}{ Sodium laurylsulfate } & 0.5 & 25 & 64 \\
\hline & 1.0 & 0 & 0 \\
\hline \multirow[t]{2}{*}{$\mathrm{CPC}^{a)}$} & 0.5 & 3 & 19 \\
\hline & 1.0 & 1 & 9 \\
\hline \multirow[t]{2}{*}{$\mathrm{CTAB}^{b)}$} & 0.5 & 0 & 2 \\
\hline & 1.0 & 1 & 0 \\
\hline \multirow[t]{2}{*}{ Aerosol OT } & 0.5 & 5 & 1 \\
\hline & 1.0 & 4 & 3 \\
\hline \multirow[t]{2}{*}{ Triton X-100 } & 0.5 & 70 & 75 \\
\hline & 1.0 & 85 & 86 \\
\hline \multirow[t]{2}{*}{ Tween 20} & 0.5 & 26 & 96 \\
\hline & 1.0 & 16 & 93 \\
\hline \multirow[t]{2}{*}{ Tween 40} & 0.5 & 5 & 75 \\
\hline & 1.0 & 4 & 84 \\
\hline \multirow[t]{2}{*}{ Span 20} & 0.5 & 0 & 0 \\
\hline & 1.0 & 0 & 0 \\
\hline \multirow{2}{*}{ Span 40} & 0.5 & 0 & 0 \\
\hline & 1.0 & 0 & 0 \\
\hline Control & & 0 & 0 \\
\hline
\end{tabular}

a) Cetylpyrimidium chloride.

b) Cetyltrimethyl ammonium bromide. recovery. GDH was also solubilized by sodium deoxycholate, Triton $\mathrm{X}-100$ and Tweens. Sodium deoxycholate, however, was found to be unsuitable for the solubilization of the enzymes, since it made the resulting enzyme solution getting viscous and some difficulty occurred in the subsequent handlings. Finally, Triton X-100 was evaluated to be the best of all for solubilization of particulate GDH and $2 \mathrm{KGDH}$ of the acetic acid bacteria. Thus, this agent was used throughout the following experiments.

Effects of Triton $X-100$ concentration, temperature and $p H$ on solubilization of particulate enzymes

The effect of Triton X-100 concentration on enzyme solubilization was tested in $0.01 \mathrm{M}$ phosphate buffer, $\mathrm{pH}$ 6.0, using particulate fraction from $G$. liquefaciens. As shown in Fig. 1, the best result of solubilization of the

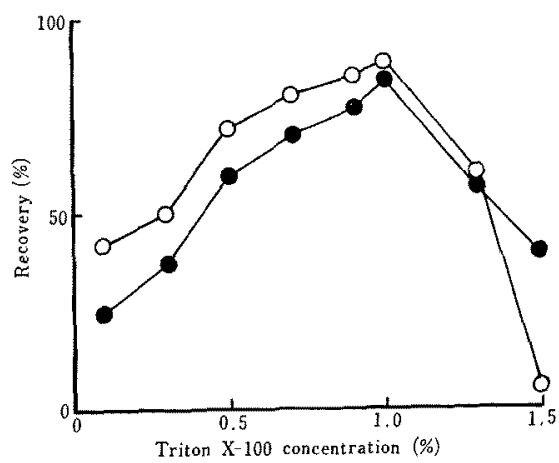

Fig. 1. Effect of Concentration of Triton X-100 on Solubilization of Particulate Enzymes.

The solubilization was carried out at $5^{\circ} \mathrm{C}$ for $9 \mathrm{hr}$ in $0.01 \mathrm{M}$ phosphate buffer, $\mathrm{pH} 6.0$. The final concentration of protein was adjusted to $30 \mathrm{mg} / \mathrm{ml}$. $\mathrm{O}-\mathrm{O}, \mathrm{GDH} ; \bullet, 2 \mathrm{KGDH}$.

particulate GDH and $2 \mathrm{KGDH}$ was obtained at 1.0 per cent of the surface active agent. The effect of temperature on enzyme solubilization was also tested in $0.01 \mathrm{M}$ phosphate buffer, $\mathrm{pH}$ 6.0. Incubation was carried out at $5^{\circ} \mathrm{C}$, $20^{\circ} \mathrm{C}$ and $30^{\circ} \mathrm{C}$. As shown in Fig. 2, incubation at $5^{\circ} \mathrm{C}$ gave a fairly good solubilization with the highest recovery of the enzyme activi- 

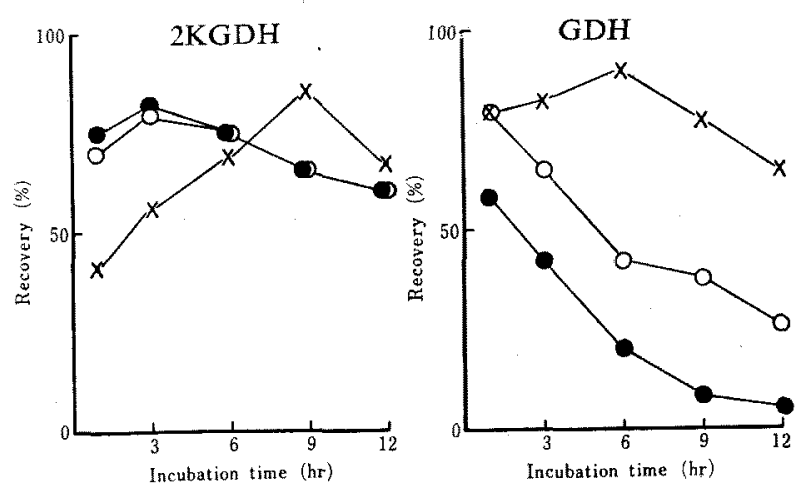

FIG. 2. Effect of Temperature on Solubilization of Particulate Enzymes.

The solubilization of the enzymes was carried out in $0.01 \mathrm{~m}$ phosphate buffer, $\mathrm{pH} 6.0$. One per cent of Triton X-100 and $30 \mathrm{mg} / \mathrm{ml}$ of protein were incubated for periods as indicated at different temperatures with continuous stirring.

$x-x, 5^{\circ} \mathrm{C} ; 0-0,20^{\circ} \mathrm{C} ; \bullet-\bullet, 30^{\circ} \mathrm{C}$.
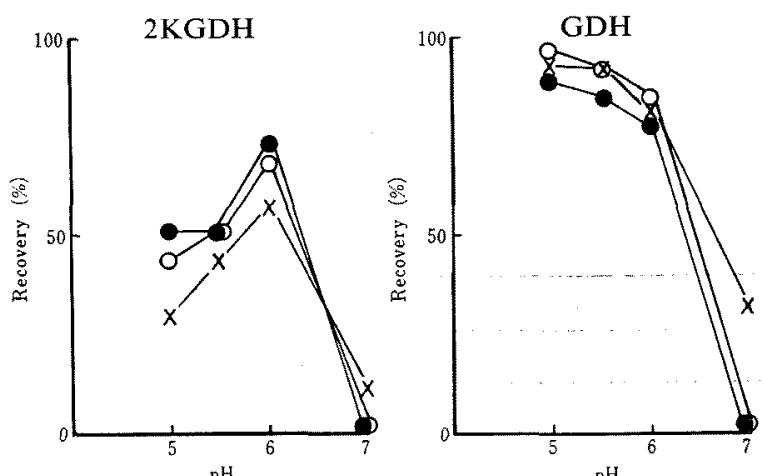

FiG. 3. Effect of pH on Solubilization of Particulate Enzymes.

The solubilization of the enzymes was carried out at $5^{\circ} \mathrm{C}$ in $0.01 \mathrm{M}$ phosphate buffer at various $\mathrm{pH}$ as indicated. One per cent of Triton $\mathrm{X}-100$ and $30 \mathrm{mg} / \mathrm{ml}$ of protein were incubated under continuous stirring.

$x-x, 3 \mathrm{hr} ; \mathrm{O}-\mathrm{O}, 6 \mathrm{hr} ; \bullet, 9 \mathrm{hr}$.

ties. Incubation at high temperature should be avoided since the enzyme activity was gradually lost during the incubation.

The effect of $\mathrm{pH}$ on enzyme solubilization was tested in $0.01 \mathrm{M}$ phosphate buffer, of which $\mathrm{pH}$ was varied as indicated in Fig. 3. A good solubilization and the highest recovery of GDH and $2 \mathrm{KGDH}$ were observed at $\mathrm{pH} 5.0$ and 6.0, respectively. As mentioned above, it was concluded that the best conditions for solubilization of particulate GDH and $2 \mathrm{KGDH}$ could be described as follows. Ten $\mathrm{mg}$ of Triton X-100 and $30 \mathrm{mg}$ of protein in $1 \mathrm{ml}$ of $0.01 \mathrm{M}$ phosphate buffer, $\mathrm{pH} 6.0$, should be incubated for $9 \mathrm{hr}$ at $5^{\circ} \mathrm{C}$ under continuous stirring. In cases of other strains of acetic acid bacteria, the same experiments were done with the particulate fraction from individual cell free extract. The results were essentially the same with $G$. liquefaciens. Other factors that might affect the conditions of solubilization of the enzymes were also extensively tested by changing the buffer concentration, with various kinds of buffer solutions, but no additional information was obtained. It is also advantageous to perform the solubilization at weak acidic $\mathrm{pH}$ range since both $\mathrm{GDH}$ and $2 \mathrm{KGDH}$ have a stable $\mathrm{pH}$ range around 6 . 


\section{Comparison between GDH and $2 K G D H$ in ele- ctric properties}

Using a highly purified enzyme preparation of $\mathrm{GDH}$ and $2 \mathrm{KGDH}$ from $G$. liquefaciens, electrophoretic analyses were carried out under the conditions described in MATERIALS AND METHODS. Electrophoretic mobilities of two particulate enzymes were different from each other and $\mathrm{Rm}$ values were obtained to be 0.48 for GDH and 0.40 for $2 \mathrm{KGDH}$. It could be concluded that particulate GDH and $2 \mathrm{KGDH}$ are different species of enzymes and have each independent character in ketogenic metabolism of carbohydrates. One would participate in $2 \mathrm{KGA}$ production and the other would catalyze the 2,5-diketogluconate formation from $2 \mathrm{KGA}$. It could be speculated that both $\mathrm{GDH}$ and $2 \mathrm{KGDH}$ are localized close to each other in subcellular localization, because either one enzyme was always accompanied by the other during the course of extraction, solubilization and purification until they were separated by ionexchange chromatography on DEAE-cellulose column (see Materials and Methods).

\section{Identification of reaction products by highly} purified particulate enzymes

Highly purified particulate GDH or $2 \mathrm{KGDH}$ from $G$. liquefaciens was incubated with $G A$ or $2 \mathrm{KGA}$, respectively, in the presence of phenazine methosulfate as an electron carrier. An aliquot of the reaction mixture was spotted on a filter paper and developed as mentioned before. ${ }^{2)}$ As shown in Fig. 4, GDH catalyzed the $2 \mathrm{KGA}$ formation from $\mathrm{GA}$ and $2 \mathrm{KGDH}$ catalyzed the conversion of 2KGA to 2,5diketogluconate only in the presence of phenazine methosulfate. This result suggests that the enzyme dehydrogenating $2 \mathrm{KGA}$ may be the same one as described by Katznelson et $a .^{9,10)}$ Katznelson et al. reported that 2KGA was oxidized by an enzyme preparation from $G$. melanogenus and the resulting product was identified to be 2,5-diketogluconate.

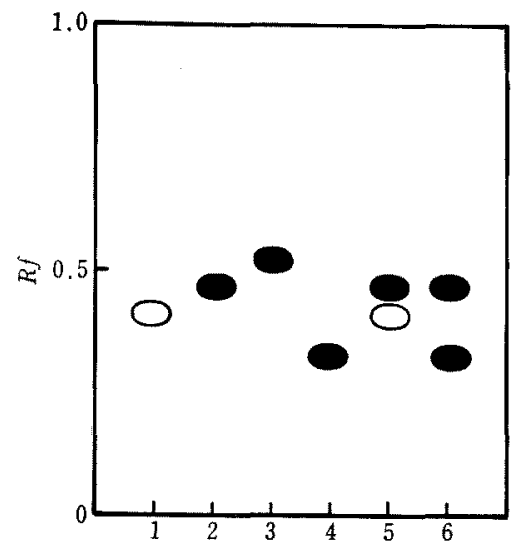

Fig. 4. Paper Chromatogram of Reaction Products by Highly Purified Enzymes.

One dimensional ascending paper chromatography on Toyo Filter Paper No. 51 was employed with tertbutanol: formate: water $(4: 1: 1.5$ by volume).

Reaction products were detected by BPB, $\bigcirc$; BPB and TTC,

1, GA; 2, 2KGA; 3, 5KGA; 4, 2,5-diketogluconate; 5, GA + GDH + phenazine methosulfate; $6,2 \mathrm{KGA}+$ $2 \mathrm{KGDH}+$ phenazine methosulfate.

Comparison between particulate enzymes and $N A D(P)$-linked enzymes

As we have suggested on glucose metabolism in acetic acid bacteria in the previous papers, ${ }^{7,18}$ that the particulate enzyme activity has a main role in ketogluconate production, while $\mathrm{NAD}(\mathrm{P})$-linked enzymes have another role to control the intracellular concentration of gluconate. Because, the NAD(P)-linked enzymes are essentially reversible in the reaction and the reduction of any ketogluconates to gluconate is extremely predominant around pH $6 .^{23}$ In addition, the particulate enzymes catalyze the oxidation of GA to $2 \mathrm{KGA}$ or $5 \mathrm{KGA}$ and the oxidation of $2 \mathrm{KGA}$ to 2,5 diketogluconate but the reverse reaction (reduction) has never occurred by the particulate enzymes so far investigated. Both NAD (P)-linked enzymes and particulate enzymes in the cell free extract of all species of acetic acid bacteria are summarized in Table IV. In this experiment, total enzyme activity of particulate enzymes was compared with that of $N A D(P)$-linked enzymes in the cell free extract, using the definition of the international unit (U). It was obvious as seen in this 
Table IV. Comparison between Particulate Enzymes and NAD(P)-Linked Enzymes in the Cell Free Extract of Acetic Acid Bacteria min).

The expression of both enzyme activities was made using the definition of the international unit ( $\mu$ mole/

\begin{tabular}{|c|c|c|c|c|}
\hline \multirow{2}{*}{ Strain } & \multirow{2}{*}{$\frac{\begin{array}{c}\text { Particulate } \\
\text { enzyme activity } \\
\text { (units/ml) }\end{array}}{\text { GA to }}$} & \multicolumn{3}{|c|}{$\begin{array}{l}\text { NAD (P)-linked } \\
\text { enzyme activity } \\
\text { (units } / \mathrm{ml} \text { ) }\end{array}$} \\
\hline & & $\begin{array}{c}\text { GA to } \\
2 \mathrm{KGA} \text { or } 5 \mathrm{KGA}\end{array}$ & $\begin{array}{c}2 \mathrm{KGA} \\
\text { to } \mathrm{GA}\end{array}$ & $\begin{array}{l}5 \mathrm{KGA} \\
\text { to } \mathrm{GA}\end{array}$ \\
\hline \multicolumn{5}{|l|}{ Acetobacter } \\
\hline A. aceti IFO 3281 & 14 & 0.45 & 1.26 & 0.61 \\
\hline A. aceti IFO 3284 & 36 & 0.10 & 1.77 & 0.35 \\
\hline A. ascendens IFO 3299 & 0 & 0 & 1.61 & 0.74 \\
\hline A. acetosus IFO 3129 & 0 & 0 & 0.81 & 0.19 \\
\hline A. xylinum IFO 3288 & 0 & 0 & 0.06 & 0.03 \\
\hline A. kützingianus IFO 3222 & 0 & 0 & 1.65 & 0.39 \\
\hline A. rancens IFO 3298 & 0 & 0.16 & 3.35 & 0.55 \\
\hline A. acetigenus IFO 3277 & 0 & 0 & 1.29 & 0.42 \\
\hline A. aurantium IFO $3245^{a)}$ & 81 & 0.32 & 2.42 & 0.26 \\
\hline A. aurantium IFO $3247^{a\}}$ & 29 & 0.06 & 0.39 & 0.11 \\
\hline \multicolumn{5}{|l|}{ Gluconobacter } \\
\hline G. liquefaciens IFO $12388^{a}$ & 200 & 0.68 & 1.81 & 0.35 \\
\hline G. melanogenus IFO $12257^{\alpha)}$ & 629 & 0.52 & 1.26 & 0.42 \\
\hline$G$, melanogenus IFO $3293^{a>}$ & 71 & 0.29 & 1.87 & 0.16 \\
\hline G. sphaericus IFO $12467^{a), 19)}$ & 814 & 0.65 & 1.55 & 0.48 \\
\hline G. oxydans IFO 3189 & 150 & 0.77 & 0.50 & 0.81 \\
\hline G. oxydans IFO 3287 & 73 & 2.47 & 2.79 & 0.25 \\
\hline G. dioxyacetonicus IFO 3272 & 700 & 0.94 & 1.65 & 1.94 \\
\hline G. cerinus IFO 3262 & 121 & 1.29 & 2.06 & 1.87 \\
\hline G. cerinus IFO 3265 & 150 & 0.61 & 1.55 & 0.97 \\
\hline G. cerinus IFO 3267 & 29 & 0.53 & 1.61 & 1.23 \\
\hline G. gluconicus IFO 3171 & 129 & 0.32 & 1.32 & 0.44 \\
\hline G. roseus IFO 3990 & 35 & 0.13 & 0.81 & 0.35 \\
\hline G. albidus IFO 3250 & 171 & 0.06 & 0.68 & 0.16 \\
\hline G. suboxydans IFO 3172 & 149 & 0.17 & 0.57 & 0.64 \\
\hline G. suboxydans IFO 12528 & 24 & 0.28 & 0.02 & 0.36 \\
\hline G. suboxydans var. $\alpha$ IFO 3254 & 43 & 0.84 & 0.48 & 3.42 \\
\hline
\end{tabular}

a) The pigment-producing strains.

table that the formation of ketogluconates by particulate enzymes was much more predominant, roughly over 100 times higher, than that by $N A D(P)$-linked enzymes. It seems likely that the NAD(P)-linked enzymes could mainly contribute to the reduction of any ketogluconates to gluconate as shown in the right frame of Table IV.

Most strains of genus' $A$ cetobacter, except $A$. aceti and $A$. aurantium, did not have the enzymes oxidizing GA to $2 \mathrm{KGA}$ or $5 \mathrm{KGA}$ in the presence or absence of electron carriers such as NAD (P) or dyes. High enzyme acti- vities of particulate $\mathrm{GDH}$ and $2 \mathrm{KGDH}$ were found in the most strains of genus Gluconobacter, particularly in pigment-producing strains of the acetic acid bacteria. It could be concluded that the basis of classification of acetic acid bacteria into two genera, Acetobacter and Gluconobacter, is also supported by enzymatic characteristics which are intrinsic nature of the acetic acid bacteria.

The details of the particulate GDH and $2 \mathrm{KGDH}$ from $G$. liquefaciens are now under processing and will be reported elsewhere. 


\section{REFERENCES}

1) J. De Ley and A. H. Stouthamer, Biochim. Biophys. Acta, 34, 171 (1959).

2) T. Chiyonobu, O. Adachi and M. Ameyama, Agr. Biol. Chem., 37, 2871 (1973).

3) M. Ameyama, T. Chiyonobu and O. Adachi, ibid., 38, 1535 (1974).

4) T. Chiyonobu, O. Adachi and M. Ameyama, ibid., 38, 1743 (1974).

5) M. Ameyama, T. Chiyonobu and O. Adachi, ibid., 38, 1377 (1974).

6) T. Chiyonobu, E. Shinagawa, O. Adachi and M. Ameyama, ibid., 39, 2263 (1975).

7) M. Ameyama, T. Chiyonobu, E. Shinagawa and O. Adachi, in preparation (1976).

8) T. Chiyonobu, E. Shinagawa, O. Adachi and M. Ameyama, Agr. Biol. Chem., 40, 175 (1976).

9) A. G. Datta and H. Katznelson, Arch. Biochem.
Biophys., 65, 576 (1956).

10) H. Katznelson, S. W. Tanenbaum and E. L. Tatum, J. Biol. Chem., 204, 43 (1953).

11) A. Tiselius, S. Hjerten and O. Levin, Arch. Biochem. Biophys., 65, 132 (1956).

12) M. Ameyama and K. Kondo, Agr. Biol. Chem., 31, 724 (1967).

13) J. M. Armstrong, Biochim. Biophys. Acta, 86, 194 (1964).

14) O. H. Lowry, N. J. Rosebrough, A. L. Farr and R. J. Randall, J. Biol. Chem., 193, 265 (1951).

15) B. J. Davis, Ann. N. Y. Acad. Sci., 121, 404 (1964).

16) M. Ameyama and K. Kondo, Agr. Biol. Chem., 31, 724 (1967).

17) T. Asai, H. Iizuka and K. Komagata, J. Gen. Appl. Microbiol., 10, 95 (1964).

18) T. Chiyonobu, E. Shinagawa, O. Adachi and $M$. Ameyama, Agr. Biol. Chem., 39, 2425 (1975).

19) M.Ameyama, Int. J. Syst. Bacteriol., 25, 365 (1975). 